\title{
Difference of mercury bioaccumulation in red mullets from the north- western Mediterranean and Black seas
}

\author{
M. Harmelin-Vivien ${ }^{a}{ }^{*}$, D. Cossa ${ }^{b}$, S. Crochet $^{c}$, D. Bănaru ${ }^{a}$, Y. Letourneur ${ }^{a}$ and C. Mellon- \\ Duval $^{\mathrm{d}}$
}

\author{
a Centre d'Océanologie de Marseille, Université de la Méditerranée, UMR CNRS 6540, Station Marine \\ d'Endoume, 13007 Marseille, France \\ ${ }^{\mathrm{b}}$ Ifremer, Centre de Méditerranée, BP 330, 83507 La Seyne sur Mer, France \\ ${ }^{c}$ Ifremer, Centre de Nantes, BP 21105, 44311 Nantes Cedex 3, France \\ ${ }^{d}$ Centre de Recherche Halieutique Méditerranéenne et Tropicale, Ifremer BP 171, 34203 Sète Cedex, France
}

*: Corresponding author: M. Harmelin-Vivien, Tel.: +33 4910416 28; fax: +33 4910416 35.email address : mireille.harmelin@univmed.fr

\begin{abstract}
:
The relationships between total mercury $(\mathrm{Hg})$ concentration and stable nitrogen isotope ratio $\left(\delta^{15} \mathrm{~N}\right)$ were evaluated in Mullus barbatus barbatus and M. surmuletus from the Mediterranean Sea and $M$. barbatus ponticus from the Black Sea. Mercury concentration in fish muscle was six times higher in the two Mediterranean species than in the Black Sea one for similar sized animals. A positive correlation between $\mathrm{Hg}$ concentration and $\delta^{15} \mathrm{~N}$ occurred in all species. Increase in $\mathrm{Hg}$ concentration with $\delta^{15} \mathrm{~N}$ was high and similar in the two Mediterranean fishes and much lower in the Black Sea species. Since this was neither related to trophic level difference between species nor to methylmercury $(\mathrm{MeHg})$ concentration differences between the north-western Mediterranean and the Black Sea waters, we suggested that the higher primary production of the Black Sea induced a dilution of $\mathrm{MeHg}$ concentration at the base of the food webs.
\end{abstract}

Keywords: ${ }^{15} \mathrm{~N}$; Trophic level; Methylmercury; Mullidae; Mediterranean; Black Sea 


\section{Introduction}

Heavy metal contamination of aquatic ecosystems is a serious problem for human health, as marine fish are important commercial sources of proteins (Phillips, 1995). This is particularly the case for mercury $(\mathrm{Hg})$, which biomagnifies along food webs (Morel et al., 1998). The risk of exposure to environmental contaminants for human beings requires an understanding of the factors affecting mercury accumulation in fish (Clarckson, 1997). This problem is particularly crucial for Mullidae, also known as red mullets, which are an important commercial resource in the Mediterranean Sea (Suquet and Person-Le Ruyet, 2001). Total catch of red mullets in the Mediterranean and Black Seas combined reached 37171 tonnes in 2005 (FAO, 2005).

Mercury uptake by fishes is a cumulative process resulting from bioaccumulation of the metal with age and biomagnification through food webs. Both processes result in an increasing $\mathrm{Hg}$ concentration with size and trophic level (e.g., Monteiro et al., 1991; Trudel and Rasmussen, 2006). Methylmercury ( $\mathrm{MeHg}$ ) is the predominant form of $\mathrm{Hg}$ in fish muscle, ranging from $80 \%$ to 98\% (Bloom, 1992; Joiris et al., 1999; Magalhães et al., 2007). In the muscle of $M$. barbatus barbatus (Capelli et al., 2004; Gonul and Kucuksezgin, 2007) and $M$. surmuletus (Capelli et al., 2004), MeHg accounted for $90 \%$ of the total $\mathrm{Hg}$ content. Thus, the analysis of total mercury in fish muscle gives a good proxy of the concentration of $\mathrm{MeHg}$ in fish muscle with more accurate and economical analytical (Bloom, 1992). Mercury accumulation in fish mainly results in a direct uptake from food that accounts for at least $85 \%$ of the total uptake of $\mathrm{MeHg}$ in fish (Hall et al., 1997). The highly toxic $\mathrm{MeHg}$ is mainly accumulated in fish muscle due to its affinity to protein (Harris et al., 2003; Amlund et al., 2007). However, incorporation of $\mathrm{Hg}$ in fish muscle is a complex process that may vary according to various biological factors (growth rate, sex, age of fish), ecological factors (food, habitat) and environmental factors ( $\mathrm{Hg}$ inputs, methylation rate, primary productivity) that explains the variety of results obtained on different species (Trudel and Rasmussen, 2006; Schwindt et al., 2008). Concentration of mercury in fish is affected by bioenergetic processes and increases generally with size and age (Trudel and Rasmussen, 2006; Magalhães et al., 2007), but this is not the rule (Schwindt et al., 2008). It also increases with trophic level of the fish, a process known as biomagnification. Stable nitrogen isotope ratio $\left(\delta^{15} \mathrm{~N}\right)$ was used in several studies to identify the trophic position of organisms and, thus, quantitatively assess $\mathrm{Hg}$ biomagnification in food webs (e.g., Cabana and Rasmussen, 1994; Jarman et al., 1996; Cai et al., 2007). Trophic level is a good predictor of $\mathrm{Hg}$ concentration in some fish, but not in other species, where $\mathrm{Hg}$ is more significantly related to other parameters (Atwell et al., 1998).

Several early papers demonstrated elevated $\mathrm{Hg}$ concentrations in the Mediterranean fishes compared to the same species from other parts of the world (e.g., Bernhard and Renzoni, 1977). Aston and Fowler (1985) reviewed the main hypotheses that may explain these observations, from the bioavailability of mercury in waters to the specificities of the Mediterranean food web structures. However, they failed to reach a clear conclusion and suggested that more data were needed to resolve these issues. Since, new results have been obtained from coastal (Barghigiani and De Ranieri, 1992; Corsi et al., 2002; Gonul and Kucuksezgin, 2007; Keskin et al., 2007) and deep water (Storelli et al., 2002; Cossa and Coquery, 2005) Mediterranean fishes. However, most studies provide $\mathrm{Hg}$ concentration in fish muscle without any explanation on the mechanisms involved, and fail to explain geographic differences. We addressed here this question in the case of Mullus species from the Gulf of Lions (NW Mediterranean) and the Romanian coast (Black Sea), since the ecology of these animals (Bautista-Vega et al., 2008; Bănaru, 2008) and the methylmercury concentrations in these waters (Lamborg et al., 2008; Cossa et al., in press) were recently documented. Bautista-Vega et al. (2008) demonstrate that the trophic level of individuals increases with size in Mullus $b$. barbatus Linnaeus, 1758 and not in M. surmuletus Linnaeus, 1758 in the Gulf of Lions (NW Mediterranean). Such a difference is related to differences in diet composition and trophic level of preys, which increases with fish size in $M$. $b$. barbatus 
but not in $M$. surmuletus. Are such differences reflected in $\mathrm{Hg}$ accumulation in these two species? The study of $M$. b. ponticus Espipov, 1927 collected on the Romanian coast (NW Black Sea) afforded the opportunity to compare $\mathrm{Hg}$ content in Mediterranean and Black Sea closely related fish species. The specific objectives of the present study was therefore to analyse the variations of $\mathrm{Hg}$ concentration in the muscle of the three red mullet species in relationship with their sex, size, age and $\delta^{15} \mathrm{~N}$, and look for difference in environmental conditions that may account for geographic differences in their $\mathrm{Hg}$ content.

\section{Material and Methods}

\subsection{Study areas and fish sampling}

Mullus $b$. barbatus and $M$. surmuletus were collected in the Gulf of Lions (NW Mediterranean, $42^{\circ} 15^{\prime}-43^{\circ} 35^{\prime} \mathrm{N}, 3^{\circ} 00^{\prime}-6^{\circ} 00^{\prime} \mathrm{E}$ ) by trawling between 20 and $90 \mathrm{~m}$ depth, and M. b. ponticus was collected on the Romanian coast (NW Black Sea, $45^{\circ} 12^{\prime}-43^{\circ} 44^{\prime} \mathrm{N}$, $29^{\circ} 40^{\prime}-28^{\circ} 35^{\prime} \mathrm{E}$ ) by trawling between 10 and $30 \mathrm{~m}$ depth in May 2004 (Fig. 1). This last subspecies is the only red mullet present in the Black Sea. Sampling in Romania was performed with fishermen who trawl in shallower fishing grounds due to the wide continental shelf extending in this region. Total length $(T L \mathrm{~cm})$, mass $(\mathrm{g})$ and sex of individuals were recorded, digestive tract removed and fixed in $5 \%$ buffered formalin, and dorsal white muscle collected and kept frozen at $-20^{\circ} \mathrm{C}$ before freeze-drying for stable isotope and mercury content analyses. Number, sex, size and age of fish individuals analysed were indicated on Table 1. Age was estimated according to the growth equations established by Bougis (1952) and Reñones et al. (1995) for these fish species in the NW Mediterranean. Red mullets are benthic feeders that prey on polychaetes, crustaceans and molluscs (Aguire and Sanchez, 2005; Bautista-Vega et al., 2008).

\subsection{Mercury analysis}

Measurements of total $\mathrm{Hg}$ in fish tissue were performed using the automated atomic absorption spectrophotometer by ALTEC (Model AMA-254). The total mercury determination procedure consists of the following automatic sequences: (1) an ashing $\left(550^{\circ} \mathrm{C}\right)$ of the freeze dried sample allowing the elemental mercury volatilisation from the sample, (2) the evolved elemental mercury amalgamation on a gold trap, (3) an atomic absorption spectrophotometric measurement of the $\mathrm{Hg}$ collected following the heating of the gold trap $\left(800^{\circ} \mathrm{C}\right)$. With a $20 \mathrm{mg}$ sample the detection limit and the reproducibility were $0.007 \mu \mathrm{g} . \mathrm{g}-1$ and $7 \%$ respectively. The accuracy of the technique was assessed every ten samples using various certified reference materials (CRM) from the National Research Council of Canada and the International Atomic Energy Agency (IAEA). These CRM were fish muscle tissues (DORM-1 and DORM-2) chosen according to the $\mathrm{Hg}$ concentration level of the samples analysed. The measured values were always within the confidence limits given for the CRM (Table 2). Mercury concentration was expressed as total Hg dry weight concentration in fish muscle ( $\mu \mathrm{g} \cdot \mathrm{g}-1 \mathrm{dw})$.

\subsection{Stable isotope analysis}

To evaluate the trophic position of individuals / stable nitrogen isotope ratio $\left(\delta^{15} \mathrm{~N}\right)$ was analysed on dorsal white muscle. Freeze-dried samples were ground into a fine powder using a mortar and pestle and $1 \mathrm{mg}$ in tin capsule was analyzed. ${ }^{15} \mathrm{~N} /{ }^{14} \mathrm{~N}$ ratios were determined by continuous-flow isotope-ratio mass spectrometry. The spectrometer was a Europa Scientific ANCA-NT 20-20 Stable Isotope Analyser with ANCA-NT Solid/Liquid Preparation Module, with an analytical precision (SD, $n=5)$ of $0.2 \%$ estimated from standards analysed along with the samples. Internal working standards were $1 \mathrm{mg}$ leucine prepared by 
freeze drying $50 \mu \mathrm{l}$ of a $20 \mathrm{mg} \mathrm{mL}^{-1}$ stock solution into tin capsules, and calibrated against IAEA standards N1 and N2. Delta notation was used as following:

$\delta X(\%)=\left[\left(R_{\text {sample }} / R_{\text {standard }}\right)-1\right] \times 10^{3}$

where $X$ is ${ }^{15} \mathrm{~N}$, and $R$ the ratio ${ }^{15} \mathrm{~N} /{ }^{14} \mathrm{~N}$. The standard reference material was atmospheric $\mathrm{N}_{2}$ for nitrogen.

\subsection{Data analysis}

Differences in mean $\delta^{15} \mathrm{~N}$ and mean total $\mathrm{Hg}$ concentration between fish species were tested using ANCOVA to eliminate the influence of fish size on data. Pearson linear regressions were conducted for exploring the relationships between $\delta^{15} \mathrm{~N}$ and total $\mathrm{Hg}$ concentration with fish size and age, as well as between $\delta^{15} \mathrm{~N}$ and total $\mathrm{Hg}$ concentration, in each of the three species studied. Relationships with weight were not tested as weight is a more variable parameter than length (Storelli et al., 2002). Differences in slope and elevation were tested by appropriate $t$-test.

\section{Results}

\subsection{Mean stable nitrogen isotope ratio and mercury content}

No difference in $\delta^{15} \mathrm{~N}$ value or total $\mathrm{Hg}$ content with sex were observed in $M$. b. barbatus ( $\mathrm{p}$ $=0.236$ and 0.265 respectively), $M$. surmuletus ( $p=0.570$ and 0.451 respectively) and $M$. $b$. ponticus ( $p=0.472$ and 0.616 respectively) for a given fish length. However, individuals larger than $21 \mathrm{~cm}$ TL in both $M . b$. barbatus and $M$. surmuletus were all females. Thus, all individuals were analysed together and sex was not further taken into consideration. No significant difference in mean $\delta^{15} \mathrm{~N}$ was observed between $M$. b. barbatus and $M$. surmuletus, the two NW Mediterranean fish species, whereas a significantly higher $\delta^{15} \mathrm{~N}$ value was recorded in the Black Sea species, $M$. b. ponticus (ANCOVA: $F=517.20, p<0.001$ ) (Table 1). Total mercury concentration was significantly lower in $M$. b. ponticus, whereas higher and similar $\mathrm{Hg}$ concentrations were recorded in the two Mediterranean species (ANCOVA: $\mathrm{F}=$ 10.08, $\mathrm{p}<0.001)$. The mean $\mathrm{Hg}$ content in the Black Sea red mullet was six times lower than that observed in the two Mediterranean species. However, the mean size and age of $M . b$. ponticus individuals analysed were lower than those of $M$. $b$. barbatus and $M$. surmuletus (Table 1). Total $\mathrm{Hg}$ concentration by $2 \mathrm{~cm}$ size classes in the three fish species studied indicated that $\mathrm{Hg}$ content was always significantly lower in the Black Sea species than in the Mediterranean ones at similar size (Fig. 2). Mercury mean concentration was from four times lower in fish smaller than $10 \mathrm{~cm}$ to six times lower in $12-14 \mathrm{~cm}$ fish in $M . b$. ponticus than in the two other species. No difference in $\mathrm{Hg}$ content between $M$. b. barbatus and $M$. surmuletus was observed for fish smaller than $20 \mathrm{~cm} \mathrm{TL}$, whereas the difference was highly significant for fish larger than $22 \mathrm{~cm} \mathrm{TL}$, with higher $\mathrm{Hg}$ values in $M$. b. barbatus (Fig. 2). Thus, at similar size Black Sea red mullets contained lower concentrations of total $\mathrm{Hg}$ than Mediterranean species, and large $M$. surmuletus presented lower $\mathrm{Hg}$ concentrations than large $M . b$. barbatus in the Gulf of Lions.

\subsection{Difference in $\delta^{15} \mathrm{~N}$ and $\mathrm{Hg}$ relationships between species}

Both $\delta^{15} \mathrm{~N}$ and total $\mathrm{Hg}$ concentration were significantly related to size and age in $M . b$. barbatus, whereas these relationships were not significant in both $M$. surmuletus and $M . b$. ponticus (Table 3). However, significant positive correlations between total $\mathrm{Hg}$ and $\delta^{15} \mathrm{~N}$ were evidenced in the three red mullets, even if explaining a low percentage of data variability (5 to $11 \%$ ) (Table 3 ). These results implied that trophic level, indicated by $\delta^{15} \mathrm{~N}$ values, was a 
better predictor of total mercury concentration than size and age in $M$. surmuletus and $M . b$. ponticus, whereas all factors were significant in $M$. $b$. barbatus. The increase in $\mathrm{Hg}$ concentration with $\delta^{15} \mathrm{~N}$ was similar in the two Mediterranean species and higher than in the Black Sea species (Fig. 3). The equations of the regression of $\mathrm{Hg}(y)$ versus $\delta^{15} \mathrm{~N}(x)$ were $y$ $=-1.592+0.257 x$ for M. b. barbatus, $y=-1.528+0.233 x$ for M. surmuletus and $y=-0.135$ $+0.020 x$ for $M$. b. ponticus. Slopes and elevations of linear regressions did not differ between $M$. b. barbatus and $M$. surmuletus $(t=0.081, p>0.05$ and $t=0.013, p>0.05$ respectively), but were significantly higher than the slope and elevation observed for $M . b$. ponticus $(\mathrm{t}=1.975, \mathrm{p}<0.001$ and $\mathrm{t}=6.528, \mathrm{p}<0.001$ respectively).

\section{Discussion}

In the present study, the relative role of sex, size, trophic position and geographical origin on $\mathrm{Hg}$ concentration in red mullets was analysed. We argued here that the $\mathrm{Hg}$ in preys and differences in the productivity between the north-western Mediterranean and the Black Sea governed $\mathrm{Hg}$ concentrations in fish tissue.

\subsection{Differences in $\mathrm{Hg}$ concentration between red mullets, a consequence of the feeding regime}

Higher mercury concentration is often observed in slow growing fishes compared to fast growing fishes (Monteiro et al.,1991). Depending on the relative growth rates, higher $\mathrm{Hg}$ concentration can be found in males or females. In spite of a difference in growth with sex in red mullets, males growing slowly than females (Reñones et al., 1995), no difference in $\mathrm{Hg}$ content with sex was observed in the three species studied, as also observed for other marine fishes (Magalhães et al., 2007). An increase in Hg with size is reported in many, but not all, marine (Joiris et al., 1999; Cai et al., 2007; Magalhães et al., 2007) and freshwater fish species (Schwindt et al., 2008). No significant relationship between $\mathrm{Hg}$ concentration and size and age was observed in $M$. surmuletus and $M$. $b$. ponticus, at least within the range of fish size and age studied, whereas $\mathrm{Hg}$ bioaccumulation was observed with the individual trophic level estimated with stable nitrogen isotope ratio. $\ln M . b$. barbatus, $\delta^{15} \mathrm{~N}$, size and age covaried suggesting that a combination of the three parameters caused the observed $\mathrm{Hg}$ accumulation. A positive relationship between $\mathrm{Hg}$ and fish size is also observed in M. b. barbatus from Italian (Corsi et al., 2002) and Turkish waters (Gonul and Kucuksezgin, 2007).

In many studies $\mathrm{Hg}$ concentration increases also with $\delta^{15} \mathrm{~N}$ within and between species (Jarman et al., 1996). The positive correlation between $\mathrm{Hg}$ concentration and trophic position $\left(\delta^{15} \mathrm{~N}\right)$ of individuals observed in the three red mullets studied indicated the importance of prey trophic level in the mercury content of these species. As the main route for $\mathrm{Hg}$ uptake in fish is food (Hall et al., 1997), it is important to know precisely the feeding ecology of species to understand the patterns observed in Hg concentration. Diet of red mullets analysed in this study has been described previously for the Mediterranean (Bautista-Vega et al., 2008) and Black Sea species (Bănaru, 2008) that allowed explaining interspecific difference in trophic position and $\mathrm{Hg}$ concentration. The significant increase in $\delta^{15} \mathrm{~N}$ with size in $M$. $b$. barbatus is explained by an increase in large polychaete and shrimp consumption and a decrease in small crustacean use (Bautista-Vega et al., 2008). In contrast, the absence of relationship between $\delta^{15} \mathrm{~N}$ and size in $M$. surmuletus is related to a more homogeneous diet with size and the ingestion of smaller prey. Thus, the difference of size-related increase in $\delta^{15} \mathrm{~N}$ between these two red mullets is linked to difference in trophic level of their main prey, as $M . b$. barbatus feeds on invertebrates of increasing trophic level when growing, and not $M$. surmuletus (Bautista-Vega et al. 2008). M. b. ponticus feeds mainly on small crustaceans and, to a lesser extent, on bivalves and polychaetes, and no change in $\delta^{15} \mathrm{~N}$ of its diet with size is observed (Bănaru, 2008). $\mathrm{Hg}$ concentration of prey is probably the primary 
determinant of $\mathrm{Hg}$ loading in fishes, as concluded by Magalhães et al. (2007). They relate a positive relationship of $\mathrm{Hg}$ concentration in fish muscle to $\mathrm{Hg}$ concentration in their diet around the Azorean Islands. Our results were consistent with the idea that the feeding of large $M . b$. barbatus on polychaetes was the reason why they accumulated more mercury in their muscle tissue than $M$. surmuletus which feed more on small crustaceans. In spite of the lack of $\mathrm{Hg}$ measurements in the preys, this hypothesis was strongly supported by numerous literature data, which show that a progressive increase in $\mathrm{Hg}$ concentrations is usually found in organisms at different levels of the marine food web (e.g., Boudou and Ribeyre, 1997). For example Bargagli et al. (1998) found systematically higher $\mathrm{Hg}$ concentration in polychaetes than in plankton in a study of an Antarctic marine ecosystem. Complementary studies on $\mathrm{Hg}$ content in prey invertebrates are thus needed to better apprehend the route of $\mathrm{Hg}$ accumulation in fishes from the Mediterranean and Black seas.

Variability in $\mathrm{Hg}$ concentration in the three red mullets studied was high, as also observed for M. b. barbatus in the Adriatic Sea (Corsi et al., 2002). Data were particularly scattered within large size classes and high trophic levels. An increase in variability in $\mathrm{Hg}$ concentration with trophic position seems to be frequent and was also noticed by Atwell et al. (1998) in an Arctic marine food web.

\subsection{Geographical differences in $\mathrm{Hg}$ concentration in the red mullets, a consequence of "biodilution"}

A literature review indicates that the highest $\mathrm{Hg}$ concentration recorded in red mullets in the Mediterranean area is observed in the Adriatic and Marmara seas, and the lowest in the Black Sea (Table 4). Thus, $\mathrm{Hg}$ concentration in one fish species seems to differ highly at a regional scale. Are these differences due to differences in fish trophic position, or in $\mathrm{Hg}$ bioavailability in the environment (i.e., concentration level, chemical species abundance, uptake efficiency by phytoplankton)?

A mean trophic level of 3.4 is calculated for similar size classes in M. surmuletus in the Gulf of Lions (Bautista-Vega et al., 2008) and M. b. ponticus on the Romanian coast (Bănaru, 2008) in spite of different $\delta^{15} \mathrm{~N}$ values. Such a result is due to a higher $\delta^{15} \mathrm{~N}$ value of phytoplankton in the Black Sea (7.85 \% $\pm 1.96 \%$, Bănaru et al., 2007) than in the Mediterranean (4.45\% $\pm 0.78 \%$, Bautista-Vega et al., 2008). Since these red mullets presented similar trophic levels, this parameter cannot account for the regional difference observed in $\mathrm{Hg}$ accumulation.

Recent papers on mercury distribution in seawaters of the Mediterranean and the Black Sea (Lamborg et al., 2008; Cossa et al., in press) bring information about mercury species abundance in both the Gulf of Lions and the Back Sea (Table 5). Albeit higher total mercury concentrations are recorded in the Black Sea compared to the Gulf of Lions, the biomagnified mercury species, the $\mathrm{MeHg}$, presents similar concentration within the first hundred metres, the water layer where the red mullets are living and feeding. However, the methylmercury concentration in phytoplankton is the result of both MeHg uptake rate and phytoplankton growth. Uptake, which is partially governed by $\mathrm{MeHg}$ concentration in water (Mason et al. 1996; Pickhardt and Fisher, 2007), will result in various MeHg concentration in plankton depending the rate of building cellular material; indeed a high primary production induces a biomass dilution phenomenon (Pickhardt et al., 2002). Joiris et al. (1995) observed a significant negative correlation between $\mathrm{Hg}$ concentration and particulate organic carbon concentration in the particulate matter of the European Arctic Seas. Their results testify from a biomass dilution phenomenon with lower contaminant concentration in highly productive waters. As the mean annual primary production recorded on the Romanian coasts (Humborg, 1997) is higher than that observed in the Gulf of Lions (Bosc et al., 2004) (Table 5 ), one could expect a lower $\mathrm{Hg}$ concentration in Black Sea than in Mediterranean phytoplankton, and subsequently a lower $\mathrm{Hg}$ accumulation along food webs. Thus, the lower $\mathrm{Hg}$ concentration recorded in the Black Sea red mullet compared to the Mediterranean species is explained most likely by the higher primary production in the Black Sea. We arrived with a similar interpretation as Outridge et al. (2008) who conclude that the 
concentration of bioavailable $\mathrm{Hg}$ in seawater is incapable to satisfactorily explaining $\mathrm{Hg}$ variations in marine biota. They hypothesise that the rate of biological uptake and trophic transfer are the key regulators of bioaccumulation and biomagnification in marine organisms. Thus, the biodilution at the base of the food web is more than probably the reason of the lower $\mathrm{Hg}$ concentration in the red mullet muscle tissue from the Black Sea compared to those of the north-western Mediterranean.

\subsection{Risk consequences}

The higher concentration of $\mathrm{Hg}$ in Mediterranean organisms compared to other seas was reported for different species. Monteiro et al. (1991) observed a higher $\mathrm{Hg}$ concentration in Mediterranean scorpionfish Helicolenus dactylopterus than in the Azorean individuals. Difference in $\mathrm{Hg}$ content in fish is also noted between different Mediterranean regions for red mullets (Table 4) and sardines (Joiris et al., 1999). Mullidae have been used for monitoring potential toxicological risk associated to edible fish in a number of studies around the Mediterranean (Storelli et al., 2003; Capelli et al., 2004; and others). The regulatory limit of the European Union for mercury concentration in demersal fishes is $0.5 \mu \mathrm{g} . \mathrm{g}^{-1}$ wet weight (EU, 2001). In our study, such level was exceeded only in $M . b$. barbatus larger than $22 \mathrm{~cm}$ $\mathrm{TL}$, whereas no indication of size could be indicated in $M$. surmuletus because $\mathrm{Hg}$ concentration was not size dependent in this last species. However, large M. surmuletus contain generally lower $\mathrm{Hg}$ concentration than large $M$. $b$. barbatus.

The results of the present study point out that fish biology, food webs structure and environmental conditions knowledge are all important for understanding the dynamics of $\mathrm{Hg}$ accumulation in commercial fish species. These findings partly answer to the "mercury enigma" in Mediterranean waters pointed out thirty years ago (Aston and Fowler, 1985). However, the study of MeHg uptake by phytoplankton and its transfer through the various components of trophic webs is a challenging issue for better understanding its bioaccumulation and biomagnification processes in marine fishes.

\section{Acknowledgements}

Thanks are expressed to the crew of RV "L'Europe" for valuable help during fish sampling in the NW Mediterranean, to the Romanian fishermen for their cooperation in fish sampling in the Black Sea, and to C. Scrimgeour (Mylnefield Lipid Analysis SCRI) for stable isotope analyses. This study was partly funded by the IFREMER MEDICIS programme, the national programmes on Coastal Ecology (PNEC) and Continental Ecosphere (ECCO) and the Romanian National Council of Scientific Research and Superior Education (CNCSIS). Thanks are expressed to anonymous reviewers for improving the manuscript.

\section{References}

Aguirre, H., Sanchez, P., 2005. Feeding resource partitioning between Mullus barbatus and M. surmuletus in the Catalan Sea (northwestern Mediterranean). Cient. Mar. 31, 429-439.

Amlund, H., Lundebye, A.K., Berntssen, M.H.G., 2007. Accumulation and elimination of methylmercury in Atlantic cod (Gadus morhua L.) following dietary exposure. Aquat. Toxicol. 83, 323-330.

Aston, S.R., Fowler, S.W., 1985. Mercury in the open Mediterranean: evidence of contamination. Sci. Total Environ. 43, 13-26.

Atwell, L, Hobson, K.A., Welch, H.E., 1998. Biomagnification and bioaccumulation of mercury in an arctic marine food web: insights from stable nitrogen isotope analysis. Can. J. Fish. Aquat. Sci. 55, 1114-1121. 
Bănaru, D., 2008. Influence des apports du Danube sur les réseaux trophiques des poissons de la côte roumaine (mer Noire). PhD dissertation, University of the Mediterranean, Marseilles, $\mathrm{Fr}$

Bănaru, D., Harmelin-Vivien, M., 2007. Variations spatio-temporelles de la signature en isotopes stables $\left(\delta^{13} \mathrm{C}\right.$ et $\left.\delta^{15} \mathrm{~N}\right)$ des eaux du Danube et des communautés marines sur les côtes roumaines de la mer Noire. Cybium 31, 167-174.

Bănaru, D., Harmelin-Vivien, M., Gomoiu, M.T., Oncu, T.M., 2007. Influence of Danube River inputs on $\mathrm{C}$ and $\mathrm{N}$ stable isotope ratios of the Romanian coastal water and sediment (Black Sea). Mar. Pol. Bull. 54, 1385-1394.

Bargagli, R., Monaci, F., Sanchez-Hernandez, J.C., Cateni, D., 1998. Biomagnification of mercury in an Antarctic marine coastal food web. Mar.Ecol. Prog. Ser. 169, 75-76.

Barghigiani, C., De Ranieri, S., 1992. Mercury content in different size classes of important edible species of the northern Tyrrhenian Sea. Mar. Poll. Bull. 24, 114-116.

Bautista-Vega, A.A., Letourneur, Y., Harmelin-Vivien, M., Salen-Picard, C., 2008. Difference in diet and size-related trophic level in two sympatric fish species, the red mullets Mullus barbatus and M. surmuletus, in the Gulf of Lions (NW Mediterranean). J. Fish. Biol. 73, 24022420.

Bernhard, M., Renzoni, A., 1977. Mercury concentrations in Mediterranean marine organisms and their environments: natural and anthropogenic origins. Thalassia Jugosl. 13, 265-272.

Bloom, N.S., 1992. On the chemical form of mercury in edible fish and marine invertebrate tissue. Can. J. Fish. Aquat. Sci. 49, 1010-1017.

Bosc, E., Bricaud, A., Antoine, D., 2004. Seasonal and interannual variability in algal biomass and primary production in the Mediterranean Sea, as derived from four years of SeaWiFS observations. Glob. Biogeochem. Cycles 18, GB 1005, doi:10.1029/2003GB002034.

Boudou, A., Ribeyre, F., 1997. Mercury in the food web: accumulation and transfer mechanisms. In: Sigel, A., Sigel, H. (Eds), Metal ions in biological systems. Marcel Dekker, New-York, Vol 34, pp. 289-314.

Bougis, P. 1952. Recherches biométriques sur les rougets (Mullus barbatus L., Mullus surmuletus L.). Arch. Zool. Exp. Gén. 89, 57-174.

Cai, Y., Rooker, J.R., Gill, G.A., Turner, J.P.,2007. Bioaccumulation of mercury in pelagic fishes from the northern Gulf of Mexico. Can J Fish Aquat Sci 64, 458-469.

Cabana, G., Rasmussen, J.B., 1994. Modelling food chain structure and contaminant bioaccumulation using stable nitrogen isotopes. Nature 372, 255-257.

Clarckson, T.W., 1997. The toxicology of mercury. Crit. Rev. Clin. Lab. Sci. 34, 369-403.

Capelli, R., Drava, G., Siccardi, C., De Pellegrini, R., Minganti, V., 2004. Study of the distribution of trace elements in six species of marine organisms of the Ligurian Sea (northwestern Mediterranean) - Comparison with previous findings. Ann. Chim. 94, 533-546.

Corsi, I., Mariottini, M., Menchi, V., Sensini, C., Balocchi, C., Focardi, S., 2002. Monitoring a marine coastal area: Use of Mytilus galloprovincialis and Mullus barbatus as bioindicators. PSZNI Mar. Ecol. 23, 138-153.

Cossa, D., Averty, B., Pirrone, N., in press. The origin of methylmercury in the open Mediterranean waters. Limnol. Oceanogr.

Cossa, D., Coquery, M., 2005. The Mediterranean mercury anomaly, a geochemical or a biological issue. Hdb. Env. Chem. 5 (part K), 177-208.

El-Sharnouby, S.A., Moharram, Y.G., Moustaffa, E.K., El-Sokkary, I.A., 1986. Mercury and selenium content and relationship in (barbouni) Mullus surmuletus from Alexandria water, Egypt. Bull. Inst. Oceanogr. Fish. ARE 12, 231-238.

EU, 2001. Commission Decision 2001/466/EC. European Community Journal 8 March 2001. FAO, 2005. FAO Yearbook. Fishery Statistics. Vol. 100/1, FAO, Roma.

Gonul, L.T., Kucuksezgin, F., 2007. Mercury accumulation and speciation in the muscle of red mullet (Mullus barbatus) and annular sea bream (Diplodus annularis) from Izmir Bay (Eastern Aegean). Mar. Poll. Bull. 54, 1962-1989. 
Hall, B.D., Bodaly, R.A., Fudge, R.J.P., Rudd, J.W.M., Rosenberg, D.M., 1997. Food as the dominant pathway of methylmercury uptake by fish. Water Air Soil Poll. 100, 13-24.

Harris, H.H., Pickering, I.J., George, G.N., 2003. The chemical form of mercury in fish. Science 301, 1203.

Humborg, C., 1997. Primary productivity regime and nutrient removal in the Danube estuary. Est. Coast. Shelf. Sci. 45, 579-589.

Jarman, W.M., Hobson, K.A., Sydeman, W.J., Bacon, C.E., McLaren, E.B., 1996. Influence of trophic position and feeding location on contaminant levels in the Gulf of the Farallones food web revealed by stable isotope analysis. Environ. Sci. Technol. 30, 654-660.

Joiris, C.R., Holsbeek, L., Laroussi Moatemri, N.,1999. Total and methylmercury in sardines Sardinella aurita and Sardina pilchardus from Tunisia. Mar. Poll. Bull. 38, 188-192.

Joiris, C.R., Laroussi Moatemri, N., Holsbeek, L., 1995. Mercury and polychlorinated biphenyls in suspended particulate matter from the European Arctic Seas. Bull. Environ. Contam. Toxicol. 55, 893-900.

Keskin, Y., Baskaya, R., Özyaral, O., Yurdun, T., Lüleci, N.E., Hayran, O., 2007. Cadmium, lead, mercury and copper in fish from the Marmara Sea, Turkey. Bull. Environ. Contam. Toxicol. 78, 258-261.

Kucuksezgin, F., Uluturhan, E., Kontas, A., Altay, O., 2002. Trace metal concentrations in edible fishes from Izmir Bay, Eastern Aegean. Mar. Poll. Bull. 44, 816-832.

Lamborg, C.H., Yiğiterhan, O., Fitzgerald, W.F., Balcom, P.H., Hammerschmidt ,C.R., Murray, J., 2008. Vertical distributions of Hg species in the Black Sea. Mar. Chem. 111, 7789.

Magalhães, M.C., Costa, V., Menezes, G.M., Pinho, M.R., Santos, R.S., Monteiro, L.R., 2007. Intra- and inter-specific variability in total and methylmercury bioaccumulation by eight marine fish species from the Azores. Mar. Poll. Bull. 54, 1654-1662.

Mason, R.P., Reinfelder, J.R., Morel, F.M.M., 1996. The uptake, toxicity, and trophic transfer of mercury in a coastal diatom. Environ. Sci. Technol. 30, 1835-1845.

Monteiro, L.R., Isidro, E.J., Lopes, H.D., 1991. Mercury content in relation to sex, size, age and growth in two species of scorpionfish (Helicolenus dactylopterus and Pontinus kuhlii) from Azorean waters. Water Air Soil Poll. 56, 359-367.

Morel, F.M.M., Kraepiel, A.M.L., Amyot, M. 1998. The chemical cycle and bioaccumulation of mercury. Ann. Rev. Ecol. Syst. 29, 543-566.

Outridge, P.M., Macdonald, R.W., Wang, F., Stern, G.A., Dastoor, A.P., 2008. A mass balance inventory of mercury in the Arctic Ocean. Environ. Chem. 5, 89-111.

Phillips, D.J.H., 1995. The chemistries and environmental fates of trace metals and organochlorines in aquatic ecosystems. Mar. Pol. Bull. 31, 193-200.

Pickhardt, P.C., Fisher, N.S., 2007. Accumulation of inorganic and methylmercury by freshwater phytoplankton in two contrasting water bodies. Environ. Sci Technol. 41, 125-131. Pickhardt, P.C., Folt, C.L., Chen, C.Y., Klaue, B., Blum, J.D., 2002. Algal blooms reduce the uptake of toxic methylmercury in freshwater food webs. P. Natl. Acad. Sci. U.S.A. 99, 44194423.

Reñones, O., Massuti, E., Morales-Nin, B., 1995. Life history of the red mullet Mullus surmuletus from the bottom-trawl fishery off the island of Majorca (north-west Mediterranean). Mar. Biol. 123, 411-419.

Schwindt, A.R., Fournie, J.W., Landers, D.H., Schreck, C.B., Kent, M.L., 2008. Mercury concentrations in salmonids from Western U.S. National Parks and relationships with age and macrophage aggregates. Environ. Sci. Technol. 42, 1365-1370.

Storelli, M.M., Giacominelli-Stuffler, R., Marcotrigiano, G.O., 2002. Total and methylmercury residues in cartilaginous fish from Mediterranean Sea. Mar. Poll. Bull. 44, 1354-1358.

Storelli, M.M., Giacominelli-Stuffler, R., Storelli, A., D'Addabbo, R., Palermo, C., Marcotrigiano, G.O., 2003. Survey of total mercury and methylmercury levels in edible fish from the Adriatic Sea. Food Add. Contam. 20, 1114-1119.

Storelli, M.M., Storelli, A., Giacominelli-Stuffler, R., Marcotrigiano, G.O., 2005.Mercury speciation in the muscle of two commercially important fish, hake (Merluccius merluccius) 
and striped mullet (Mullus barbatus) from the Mediterranean Sea: estimated weekly intake. Food Chem. 89, 295-300.

Suquet, M., Person-Le-Ruyet, J., 2001. Les rougets barbets (Mullus barbatus, Mullus surmuletus). Biologie, pêche, marché et potentiel aquacole. Edition Ifremer, Brest, $47 \mathrm{p}$.

Trudel, M., Rasmussen, J.B., 2006. Bioenergetics and mercury dynamics in fish: a modelling perspective. Can. J. Fish. Aquat. Sci. 63, 1890-1902. 


\section{Tables}

Table 1

Sampling location, number (No) and age (year) of fish analysed in the three red mullet species studied, with mean ( \pm SD) fish total length (TL $\mathrm{cm}), \delta^{15} \mathrm{~N}(\%)$ and total $\mathrm{Hg}$ content ( $\mu \mathrm{g} \cdot \mathrm{g}^{-1}$ dry weight). Minimal and maximal values (min-max) were indicated into brackets. $\mathrm{M}=$ number of males, $\mathrm{F}=$ number of females.

\begin{tabular}{|c|c|c|c|c|c|c|}
\hline Species & Location & No. (M/F) & $\begin{array}{l}\text { Age (yr) (min- } \\
\max )\end{array}$ & TL (cm) (min-max) & $\delta^{15} \mathrm{~N}(\%)$ (min-max) & $\begin{array}{l}\mathrm{Hg}\left(\mu g \cdot g^{-1}\right. \\
\max )\end{array}$ \\
\hline $\begin{array}{l}\text { Mullus barbatus } \\
\text { Mullus } \\
\text { surmuletus } \\
\text { Mullus } \\
\text { ponticus }\end{array}$ & $\begin{array}{l}\text { NW } \\
\text { Mediterranean } \\
\text { NW } \\
\text { Mediterranean } \\
\text { NW Black Sea }\end{array}$ & $\begin{array}{ll}132 & (50 / 82) \\
85 & (30 / 55) \\
91 & (55 / 36)\end{array}$ & $\begin{array}{l}0.6-6.0 \\
0.5-6.2 \\
0.5-1.5\end{array}$ & $\begin{array}{l}14.8 \pm 3.6(8.5-24.5) \\
16.6 \pm 4.6(9.6-31.0) \\
10.4 \pm 1.6(7.3-14.8)\end{array}$ & 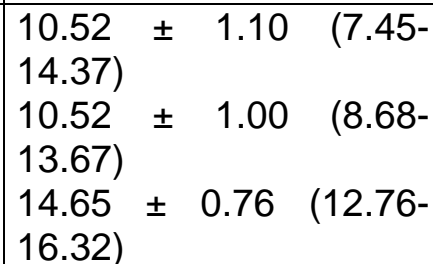 & $\begin{array}{l}1.11 \pm 1.15(0.02-8.92) \\
0.92 \pm 1.06(0.001-6.06) \\
0.16 \pm 0.05(0.09-0.33)\end{array}$ \\
\hline
\end{tabular}

Table 2

Accuracy testing of the $\mathrm{Hg}$ determinations using Certified Reference Materials. Averages and confidence intervals at $95 \%$ for the certified and found values ( $\mu \mathrm{g} \mathrm{g}^{-1} \mathrm{dw}$ ). DORM-1 and DORM-2 are fish tissues.

\begin{tabular}{|l|l|l|}
\hline & DORM-1 & DORM-2 \\
\hline Certified values & $0.798 \pm 0.074$ & $4.36 \pm 0.26$ \\
Found values & $0.854 \pm 0.013$ & $4.41 \pm 0.08$ \\
\hline
\end{tabular}


Table 3

Results of Pearson linear correlations (R) performed on $\delta^{15} \mathrm{~N}(\%)$ and total $\mathrm{Hg}$ content $\left(\mu \mathrm{g} \cdot \mathrm{g}^{-1} \mathrm{dw}\right)$ versus total length (TL cm) and age (yr) in mullid species. ns $=$ not significant.

\begin{tabular}{|c|c|c|c|c|c|}
\hline & $\delta^{15} \mathrm{~N}$ vs TL & $\mathrm{Hg}$ vs TL & $\delta^{15} \mathrm{~N}$ vs Age & Hg vs Age & $\mathrm{Hg}$ vs $\delta^{15} \mathrm{~N}$ \\
\hline $\begin{array}{l}\text { Mullus barbatus } \\
\text { Mullus surmuletus } \\
\text { Mullus b. ponticus }\end{array}$ & $\begin{array}{l}R=0.47, \quad p<0.001 \\
R=0.15, \quad p=0.176 \\
n s \\
R=0.03, \quad p=0.766 \\
n s\end{array}$ & $\begin{array}{l}R=0.59, \quad p<0.001 \\
R=0.01, \quad p=0.918 \\
n s \\
R=-0.06, \quad p=0.540 \\
n s\end{array}$ & $\begin{array}{l}R=0.45, \quad p<0.001 \\
R=0.16, \quad p=0.133 \\
n s \\
R=0.04, \quad p=0.696 \\
n s\end{array}$ & $\begin{array}{l}R=0.68, \quad p<0.001 \\
R=-0.02, \quad p=0.869 \\
n s \\
R=-0.03, \quad p=0.771 \\
n s\end{array}$ & $\begin{array}{ll}R=0.25, & p=0.003 \\
R=0.22, & p=0.042 \\
R=0.33, & p=0.002\end{array}$ \\
\hline
\end{tabular}

Table 4

Mean $( \pm \mathrm{SD}$ ) total $\mathrm{Hg}$ concentration in Mullus $b$. barbatus, $M$ b. ponticus and $M$. surmuletus muscle in the Mediterranean and adjacent waters.

Concentrations were expressed as $\mu \mathrm{g} \cdot \mathrm{g}^{-1}$ wet weight (ww). Dry weight to wet weight conversion for the present study data was done using the equation: $\mathrm{Hg}_{\text {wet weight }}=\mathrm{Hg}_{\text {dry weight }}$ * 0.22 (Magalhães et al., 2007). Min-Max = minimum and maximum values. n.a. = data not available.

\begin{tabular}{|l|l|l|l|}
\hline Locations & Mean $\pm \mathrm{SD}\left(\mathrm{Hg} \mu \mathrm{g} \cdot \mathrm{g}^{-1} \mathrm{ww}\right)$ & Min-Max $\left(\mathrm{Hg} \mu \mathrm{g} \cdot \mathrm{g}^{-1} \mathrm{ww}\right)$ & Reference \\
\hline Mullus barbatus barbatus & & & \\
NW Mediterranean (Gulf of Lions) & $0.244 \pm 0.253$ & $0.004-1.962$ & Present study \\
NW Mediterranean (Ligurian sea) & $0.200 \pm 0.042$ & $0.030-0.910$ & Capelli et al. 2004 \\
South Adriatic and Ionian Sea & $0.221 \pm 0.175$ & $<0.001-1.500$ & Corsi et al. 2002 \\
Ionian Sea & $0.400 \pm 0.420$ & $0.080-1.740$ & Storelli et al. 2005 \\
Adriatic Sea & $0.490 \pm 0.540$ & $0.027-0.399$ & Storelli et al. 2005 \\
Kucuksezgin et al. 2002 \\
Aegean Sea (Izmir Bay) & $0.155 \pm 0.117$ & Gonul and Kucuksezgin 2007 \\
Aegean Sea (Izmir Bay) & $0.063 \pm 0.051$ & & Keskin et al. 2007 \\
Marmara Sea & $0.434 \pm 0.013$ & $0.021-0.072$ & Present study \\
Mullus barbatus ponticus & & & \\
Black Sea (Romanian coast) & $0.035 \pm 0.011$ & $<0.001-1.212$ & Present study \\
Mullus surmuletus & & $0.040-0.930$ & Capelli et al. 2004 \\
NW Mediterranean (Gulf of Lions) & $0.202 \pm 0.233$ & $0.466-3.229$ & El-Sharnouby et al. 1986 \\
NW Mediterranean (Ligurian sea) & $0.210 \pm 0.066$ & 0.600 & \\
SE Mediterranean (Egypt) & & \\
\hline
\end{tabular}


Table 5

Primary production and mercury species in the north-western Mediterranean (Gulf of Lions) and the north-western Black Sea (Romanian coast). Mean total $\mathrm{Hg}$ and methylmercury were quantified in shallow seawater (0-100 $\mathrm{m}$ depth). min-max = minimum and maximum values.

References : [1] Bosc et al. 2004, [2] Cossa et al. in press, [3] Humborg 1997, [4] Lamborg et al. (2008)

\begin{tabular}{|c|c|c|}
\hline & NW Mediterranean & NW Black Sea \\
\hline $\begin{array}{l}\text { Primary production }\left(\mathrm{gC} \mathrm{m}^{-2} \mathrm{yr}^{-1}\right)(\text { mean } \pm \mathrm{SD})(\text { min-max }) \\
\text { Total } \mathrm{Hg}\left(\mathrm{ng} \mathrm{L}^{-1}\right)(\text { mean } \pm \mathrm{SD})(\text { min-max }) \\
\text { Methylmercury }\left(\mathrm{ng} \mathrm{L}^{-1}\right)(\text { mean } \pm \mathrm{SD})(\text { min-max }) \\
\text { Methylmercury /Total Hg (\%) }\end{array}$ & $\begin{array}{l}193 \pm 11(73-401)^{[1]} \\
0.26 \pm 0.03(0.22-0.32)^{[2]} \\
0.023 \pm 0.021(<0.004-0.050)^{[2]} \\
8.8 \pm 7.3(1.6-19.0)^{[2]}\end{array}$ & $\begin{array}{l}445 \pm 365(73-1606)^{[3]} \\
0.73 \pm 0.43(0.36-2.80)^{[4]} \\
0.021 \pm 0.019(0.007-0.069)^{[4]} \\
3.0 \pm 1.6(0.8-5.9)^{[4]}\end{array}$ \\
\hline
\end{tabular}




\section{Figures}

Fig. 1. Location of sampling sites in NW Mediterranean ( $1=$ Gulf of Lions $)$ and NW Black Sea $(2=$ Romanian coast $)$

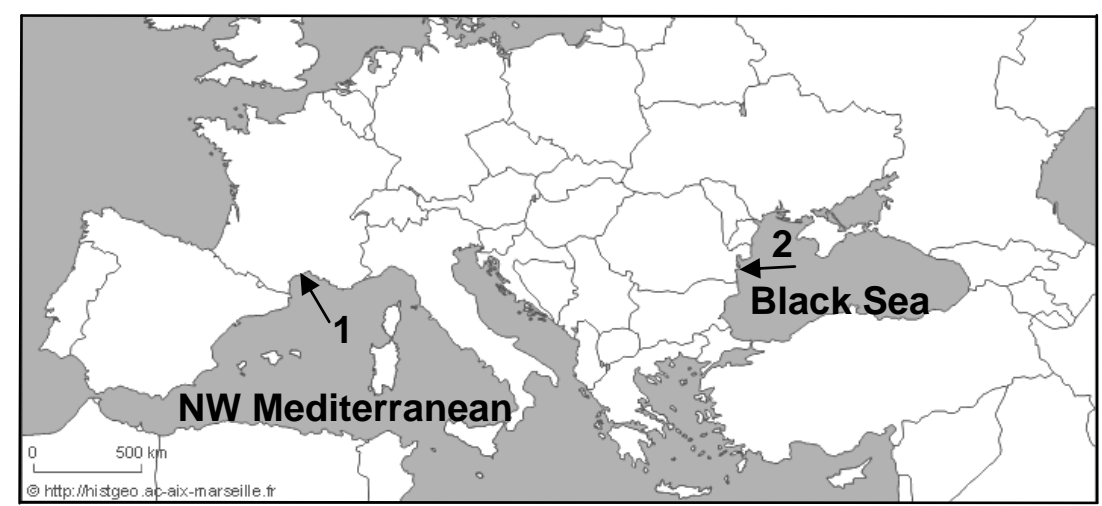


Fig. 2. Mean $\mathrm{Hg}$ concentration ( $\mu \mathrm{g} \cdot \mathrm{g}^{-1} \mathrm{dw}$ ) in Mullus barbatus, $M$. surmuletus and $M . b$. ponticus with total fish length by $2 \mathrm{~cm}$-size classes. Difference between mean concentration in $M$. b. barbatus and $M$. surmuletus in each size class was indicated above bars: ** = significant at $p<0.01,{ }^{*}=$ significant at $p<0.05$, ns $=$ not significant. Mean concentrations in $M$. $b$. ponticus were always significantly lower than in the two other species at $p<0.001$. The additional dashed line indicated the EU criteria for $\mathrm{Hg}$ concentration.

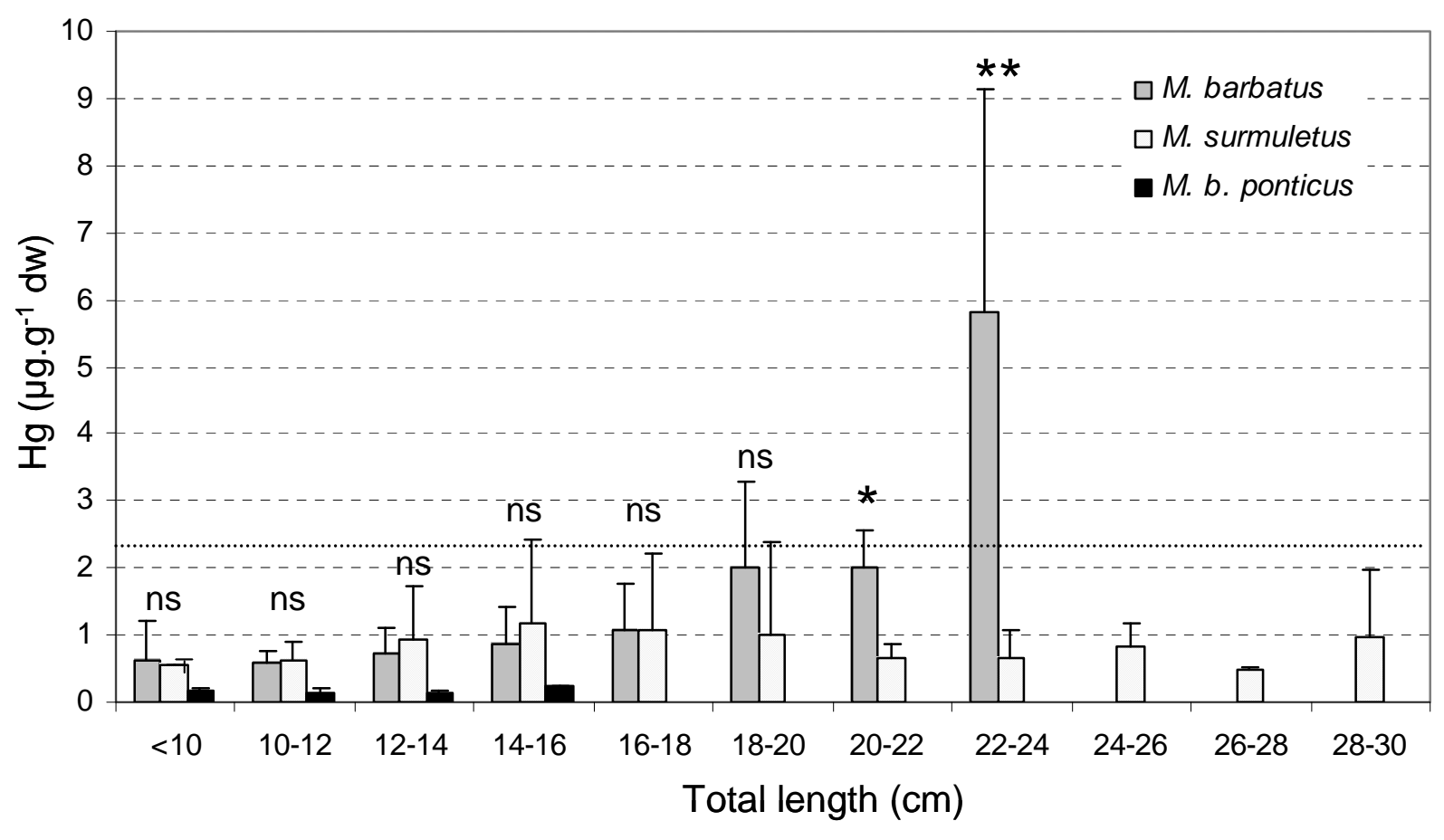

Fig. 3. Relationship between $\mathrm{Hg}$ concentration $\left(\mu \mathrm{g} \cdot \mathrm{g}^{-1} \mathrm{dw}\right)$ and $\delta^{15} \mathrm{~N}(\%)$ in the three mullid fish species studied

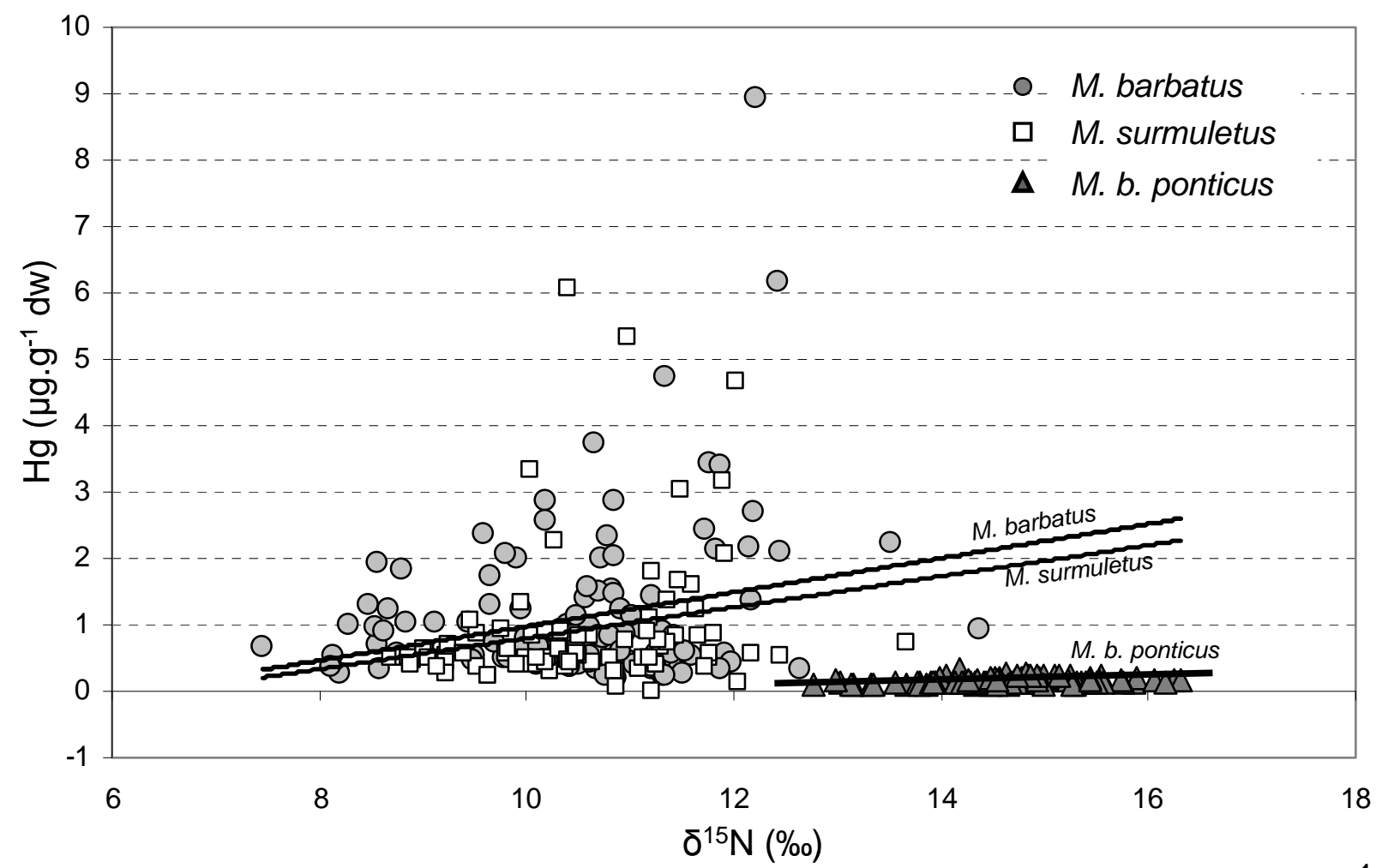

